\title{
A TRIBUTE TO THE PROFESSOR
}

At the recent meeting of the American Society of Church History in New York I was recollecting with a friend our common experience in a graduate seminar at the University of Chicago. In the course of that conversation we came to realize that the majority of the papers from the seminar eventually had found their way into print, in one form or another. We noted with satisfaction how seeds planted years ago had borne some fruit, but with that curious admixture of emotions that men and women reserve for their academic mentors, we also understood that finally the seminar was another page of testimony to the energetic intellectual leadership of the professor who had conducted it, Jerald C. Brauer.

One of the characteristic features of Professor Brauer's own scholarly work has been attention to method. Over thirty years ago, he began calling on historians of religion in America to develop interpretive methods and research strategies that would bring to the surface of the history the religious element in all of its various forms. With an eye to the promising developments at that time taking place in the emergent field of the history of religions, Professor Brauer urged historians to broaden their view of ends and means in historical scholarship. In the classroom, his influence in this regard was inescapable. Students who brought to his seminars even a small measure of willingness to engage the material in new ways quickly discovered that myth, ritual, and community were much richer categories of analysis than they had previously suspected. Under Professor Brauer's constant prodding, those students developed a facility for the precise and judicious utilization of interpretive models drawn from the theoretical and metahistorical literature, and in the process they gained a much fuller appreciation for the diversity and complexity of American religious history.

Professor Brauer's effectiveness in transmitting to students a sense of the possibilities for creatively exploring religious history stems from his own range as a historian and from his mastery of historiography. His grasp of patterns of similarities and differences among religious groups (the raw material of social-scientific theories of religion) emerged as a product of his own detailed historical study of the Reformation, English Puritanism, and religion in America. Accordingly, his lectures featured illustrative examples drawn from primary sources, never abstractions or technical jargon. History as he taught it was alive and embodied, serious and funny (and rich inspiration for the invention of puns). We knew that history was subject to revision, but Professor Brauer found subtle ways to remind us that earlier generations of historians were not always as myopic as we might think. Students interested in method flourished in his classes not only because he shared that interest, but because he slowly yet surely added perspective, and sometimes much-needed corrective ballast to the theories of young scholars bent on rewriting the story. 
Outside the classroom, where the most important exchanges between student and teacher take place, Professor Brauer's friendliness and humor set the tone for discussions that inevitably ended in his offering a cogent summary of criticisms and encouragements, like so many carrots and sticks, as the next appointment knocked on his door. Students within and without the walls of Swift Hall knew of his willingness to become involved in dissertations, either as director, reader, or informal guide. His historical breadth and his reputation for service as an adviser led to his participation in an enormously varied range of projects. But above all, his persona as a teacher was characterized by patience. I will not forget a class meeting in a hot, stuffy room in which a student presentation, because of its plodding length and nervous wandering, came close to inciting the captive audience to an experiment with human sacrifice. As the presentation ended and we prepared to vent our frustrations, Professor Brauer abruptly interceded on behalf of the frazzled student, gave face to the presentation, and pointed to a promising theme. I do not think that the lesson was lost on anyone sitting around the table.

Professor Brauer's own research is focused on Puritanism, revivalism, and regionalism in American history. His analysis of conversionism in American religious history has influenced a generation of scholars, and his attention to cultural differences associated with geographic location has been equally important in shaping historians' sense of diversity in religion in North America. Several of the articles in this issue of Church History have been chosen to represent these themes. Amanda Porterfield's study of women's attraction to Puritanism, Frank Lambert's analysis of the promotion of George Whitefield's revivals, and my own article on early Congregationalist piety directly address topics that have been at the center of Professor Brauer's research. John G. Stackhouse's study of evangelicalism in Canada adds a regionalist perspective to our view of conversionist Christianity in North America. Other articles in this issue of the journal are included as representations of the range of Professor Brauer's interests. Reflected in the scholarship of Peter Iver Kaufman and Ralph Keen, two of the many people who worked with him at Chicago, is Professor Brauer's wide-ranging interest in the history of Christianity.

Professor Brauer's service to Church History spanning four decades is but one instance of his dedication to promoting the very best scholarship, debate, and learning. His students, colleagues, and friends join me in expressing here our deepest gratitude for his extraordinary efforts as an editor, scholar, and teacher. Through him, the Society, the journal, the Divinity School, and the study of the history of Christianity all have been immeasurably enriched. Most importantly, as those of us who were in that seminar years ago know well, Jerald Brauer has helped us all to see things that we otherwise would have missed, and for that we honor him. 